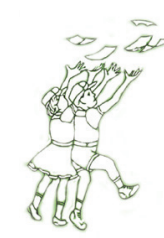

\author{
Wahana Sekolah Dasar \\ Tahun 26 Nomor 2 Juli 2018 \\ Hlm 36-42 \\ Tersedia Online di http://journal2.um.ac.id/index.php/wsd/ \\ ISSN 0854-8293 (cetak) ISSN 2622-5883 (online)
}

\title{
PENINGKATAN KETERAMPILAN MENULIS PUISI MELALUI MODEL CONTEXTUAL TEACHING AND LEARNING (CTL)
}

\author{
Ayuk Febriana, Sutansi, Alif Mudiono \\ PP3 Jl. Ir. Soekarno No.1 Blitar, Universitas Negeri Malang \\ e-mail:febrianaayuk86@gmail.com
}

\begin{abstract}
Abstrak: Keterampilan menulis puisi siswa rendah disebabkan pemahaman siswa dalam menulis puisi yang masih kurang. Tujuan penelitian untuk mendeskripsikan penerapan model contextual teaching and learning (CTL) dalam menulis puisi dan peningkatan keterampilan menulis puisi melalui model contextual teaching and learning (CTL). Penelitian dilaksanakan dalam dua siklus terdiri dari 4 tahap meliputi perencanaan, pelaksanaan, pengamatan, dan refleksi. Teknik analisis data meliputi reduksi data, penyajian data dan penarikan kesimpulan. Berdasarkan hasil penelitian dapat disimpulkan bahwa penerapan model CTL dapat meningkatkan hasil keterampilan siswa dalam menulis puisi.
\end{abstract}

Kata kunci: peningkatan hasil keterampilan, menulis puisi, model ctl

Menulis puisi merupakan kegiatan mengungkapkan ide atau gagasan melalui tulisan dengan menggunakan kata-kata yang indah dan kaya akan makna. Pembelajaran menulis puisi dilakukan dengan memperhatikan langkahlangkah dalam menulis puisi. Mckay (dalam Haryadi, 1996: 78) "mengemukakan bahwa langkah menulis puisi terdiri dari tujuh tahap. (1) pemilihan tema, (2) pengumpulan bahan, (3) penyusunan bahan, (4) pembuatan kerangka karangan, (5) penulisan naskah awal, (6) revisi, dan (7) penulisan naskah akhir".

Berdasarkan hasil wawancara yang telah dilakukan terhadap proses pembelajaran, terdapat beberapa permasalahan yaitu menulis puisi yang diketahui siswa adalah menulis yang jumlah barisnya selalu 6 baris dan menulis puisi selalu diawali dengan kata "oh". Hal ini disebabkan karena pembelajaran yang dilakukan lebih berpusat pada guru, guru kurang memberikan bimbingan, dan guru dalam melakukan pembelajaran hanya menggunakan buku paket.
Berdasarkan KKM yang telah ditentukan pada mata pelajaran bahasa Indonesia yaitu 70 , dari 8 siswa hanya 2 siswa yang mendapat nilai diatas KKM dan 6 siswa lainnya mendapat nilai dibawah KKM.

Permasalahan tersebut dapat diperbaiki dengan menerapkan model pembelajaran CTL. Menurut (Trianto, 2007) CTL adalah "konsep belajar yang membantu guru mengaitkan antara materi yang diajarkannya dengan situasi dunia nyata siswa dan mendorong siswa membuat hubungan antara pengetahuan yang dimilikinya dengan penerapannya dalam kehidupan sehari-hari”. Model CTL menekankan kepada keterlibatan siswa secara penuh untuk menemukan materi yang dipelajarinya dan menghubungkannya dengan situasi kehidupan nyata, sehingga siswa didorong untuk dapat menerapkannya dalam kehidupan siswa. Model CTL mempunyai kelebihan yang tidak dimiliki oleh model pembelajaran lain. Kelebihan tersebut diantaranya (1) dapat menekankan aktivitas berpikir siswa secara penuh, (2) dapat menjadikan siswa belajar 
dengan proses berpengalaman dalam kehidupan nyata, (3) kelas dalam kontekstual bukan sebagai tempat untuk memperoleh informasi, akan tetapi sebagai tempat untuk menguji data hasil temuan mereka di lapangan, dan (4) materi pelajaran ditentukan oleh siswa sendiri bukan hasil pemberian dari orang lain.

Berdasarkan permasalahan diatas, maka tujuan dari penelitian adalah untuk memaparkan penerapan model CTL dalam meningkatkan keterampilan menulis puisi pada siswa kelas III SDI Darut Taqwa Beji Tulungagung dan peningkatan hasil keterampilan menulis puisi setelah dilakukan penerapan model CTL pada siswa kelas III SDI Darut Taqwa Beji Tulungagung.

\section{METODE}

Penelitian menggunakan pendekatan kualitatif dengan jenis penelitian tindakan kelas (PTK). Pendekatan kualitatif menggunakan data berupa kata-kata atau pernyataan-pernyataan, lalu data dianalisis secara kualitatif dengan tujuan untuk menemukan permasalahan yang tampak. Rancangan PTK menurut Kemmis dan Taggart (dalam Arikunto, 2015). Penelitian dilakukan sebanyak dua siklus, setiap siklus dalam tahapan PTK meliputi perencanaan, pelaksanaan, pengamatan, dan refleksi.

Data yang digunakan dalam penelitian meliputi data proses dan data hasil keterampilan siswa menulis puisi menggunakan model CTL. Data proses meliputi aktivitas guru dan aktivitas siswa selama kegiatan pembelajaran. Data hasil meliputi hasil keterampilan siswa yang mencakup aspek sikap dan keterampilan. Sumber data dari penelitian adalah guru dan siswa kelas III SDI Darut Taqwa Beji Tulungagung. Pengumpulan data dalam penelitian menggunakan lima teknik yaitu, wawancara, observasi, tes, dokumentasi, dan catatan lapangan. Keenam teknik ini menggunakan instrumen pengumpul data untuk mempermudah dalam mengumpulkan data sehingga pengumpulan data lebih cermat, lengkap, dan sistematis. Instrumen yang digunakan pada penelitian ini adalah lembar wawancara, lembar observasi, lembar tes, dokumentasi, dan catatan lapangan.

Analisis data, evaluasi, dan refleksi dilaksanakan dari awal hingga akhir kegiatan penelitian. Analisis diawali dengan pengumpulan data dari hasil wawancara, observasi, tes, dokumentasi, dan catatan lapangan. Data dianalisis dengan reduksi data, penyajian data, dan penarikan kesimpulan. Hasil data observasi aktivitas guru, aktivitas siswa, sikap dan keterampilan siswa selama pembelajaran dihitung berdasarkan rumus yang ditentukan. Setelah diperoleh hasil keterampilan menulis puisi, kemudian siswa dikelompokkan antara siswa yang tuntas dan belum tuntas belajar, baik secara individu maupun klasikal.

Siswa dikatakan tuntas secara individu apabila nilainya $\geq$ KKM (70), sedangkan siswa yang belum tuntas apabila nilainya di bawah KKM. Sedangkan siswa dikatakan tuntas belajar secara klasikal apabila 75\% siswa dalam satu kelas telah mencapai nilai 70 .

\section{HASIL}

Berdasarkan pembelajaran menulis puisi yang dilakukan oleh guru diperoleh data pada tahap pratindakan yaitu persentase kegiatan pelaksanaan pembelajaran yang dilakukan guru sebesar 56\%. Ini menunjukkan 44\% kegiatan pelaksanaan pembelajaran belum muncul. Hasil data observasi pratindakan, diperoleh data bahwa rata-rata nilai siswa kelas III adalah 53. Siswa tuntas dalam pembelajaran jika mencapai nilai 70 atau sama dengan 70 . Dari 8 siswa belum ada siswa yang tuntas. Sebagai upaya meningkatkan hasil keterampilan menulis puisi maka dilakukan perbaikan dalam pembelajaran yaitu menggunakan model CTL. Hasil observasi terhadap data aktivitas guru, aktivitas siswa, dan hasil keterampilan menulis puisi selama siklus I sebagai berikut

Data persentase aktivitas guru selama pembelajaran pada siklus 1 pertemuan 1 sebe- 
sar $77 \%$ dan pertemuan 2 sebesar $85 \%$. Rata-rata persentase aktivitas guru pada siklus I sebesar $81 \%$. Pada siklus II pertemuan I persentase sebesar $92 \%$ dan pertemuan 2 sebesar $100 \%$. Persentase nilai rata-rata aktivitas guru pada siklus II sebesar 96\%. Ini menunjukkan bahwa guru telah melaksanakan pembelajaran menulis puisi menggunakan model CTL dengan sangat baik dan mengalami peningkatan.

Data persentase aktivitas siswa pada pertemuan 1 sebesar $61 \%$ dan pertemuan 2 sebesar $77 \%$ Rata-rata persentase aktivitas siswa pada siklus I sebesar 69\%. Pada siklus II pertemuan 1 didapatkan persentase sebesar $85 \%$ dan pertemuan 2 sebesar $100 \%$. Persentase nilai rata-rata aktivitas siswa pada siklus II sebesar 92\%. Hal ini membuktikan bahwa aktivitas siswa pada siklus I dan siklus II mengalami peningkatan.

Data keterampilan siswa selama mengikuti kegiatan pembelajaran pada siklus I pertemuan 1 rata-rata nilai keterampilan siswa sebesar 71 dengan Ketuntasan Belajar Klasikal (KBK) sebesar 50\% dengan predikat kurang sekali dan pertemuan 2 rata-rata nilai keterampilan siswa sebesar 77 dengan KBK sebesar 75\% dengan predikat cukup. Keterampilan siswa pada siklus I sebesar 74 dengan KBK pada siklus 1 sebesar $62 \%$ dengan predikat kurang.

Pada pembelajaran siklus I, pembelajaran melalui model CTL sudah mengalami peningkatan, namun belum maksimal. Masih terdapat beberapa catatan-catatan untuk memperbaiki proses pembelajaran pada siklus berikutnya. Sehingga dapat memperbaiki aktivitas guru dan aktivitas siswa, serta hasil keterampilan menulis puisi dan KBK yang ditentukan.

Data keterampilan siswa selama mengikuti kegiatan pembelajaran pada siklus II didapatkan hasil pada pertemuan 1 rata-rata nilai keterampilan siswa adalah 86 dengan KBK sebesar $100 \%$ dengan predikat sangat baik dan pertemuan 2 rata-rata nilai keterampilan siswa adalah 81 dengan KBK sebesar $87 \%$ dengan predikat baik. Hasil rata-rata persentase keterampilan siswa pada siklus II yaitu sebesar 84 dengan KBK sebesar 92\% dengan predikat sangat baik.

Pada pembelajaran siklus II, akivitas guru dan aktivitas siswa serta hasil keterampilan siswa mengalami peningkatan. (1) siswa sudah mandiri dalam mengerjakan tugas dan guru hanya mengawasi siswa, (2) guru sudah mampu mengkondisikan siswa sehingga siswa sudah bisa bekerjasama dengan baik, (3) guru sudah memberikan penilaian pada puisi siswa, (4) guru sudah merefleksi pembelajaran. Berdasarkan hasil pada siklus II nilai siswa sudah memenuhi KKM yaitu 70 sehingga pelaksanaan pembelajaran menulis puisi menggunakan model CTL dihentikan tanpa perlu melanjutkan pada siklus III.

Temuan penelitian yang diperoleh pada siklus I dan siklus II yaitu, (1) siswa mandiri dalam mengerjakan tugas sehingga penerapan model CTL tebukti efektif karena siswa menjadi lebih semangat dan mudah dalam belajar, (2) pembelajaran menjadi lebih bermakna karena siswa bekerjasama bersama kelompok dan siswa belajar secara langsung ke objek yang dituju sehingga siswa menjadi lebih paham serta dapat meningkatkan aktivitas siswa dan hasil keterampilan siswa, (3) guru memberikan penilaian tehadap puisi siswa sehingga penerapan model CTL membuat siswa lebih memahami materi dan dapat memperbaiki keterampilan menulis puisi, (4) nilai rata-rata pratindakan yang semula 53 dengan persentase KBK sebesar 0\% meningkat menjadi 74 dengan persentase KBK 62\% pada siklus I, meskipun nilai rata-rata siswa sudah mencapai KKM namun KBK siswa belum mencapai kriteria yang ditentukan yaitu $75 \%$ maka pembelajaran dilanjutkan ke siklus II dan di dapat nilai rata-rata sebesar 84 dengan persentase KBK sebesar $100 \%$, dan (5) disamping mempunyai kebaikan, ternyata model CTL juga mempunyai rintangan ketika mengkondisikan siswa pada pelaksanaan pembelajaran di tempat pengamatan, guru harus bisa mengatur siswa agar dapat melaksanakan pembelajaran dengan baik. 


\section{PEMBAHASAN}

\section{Penerapan model CTL dalam} meningkatkan keterampilan menulis puisi pada siswa kelas III SDI Darut Taqwa Beji Tulungagung

Pelaksanaan pembelajaran yang dilakukan guru pada siklus I belum melibatkan siswa secara aktif melalui kegiatan inkuiri dalam mengumpulkan bahan, karena siswa masih terbiasa dengan pembelajaran yang dilakukan oleh guru kelas yaitu model pembelajaran ekspositori. Sehingga siswa hanya mendengarkan penjelasan guru dan mengerjakan tugas. Hal ini sesuai dengan pendapat Riyanto (2012: 280) bahwa model pembelajaran ekspositori merupakan model pembelajaran yang didominasi oleh guru. Proses pembelajaran biasanya dimulai dari teori kemudian dilanjutkan dengan latihan soal, pada model pembelajaran ini aktivitas siswa hanya terbatas pada mendengarkan dan menulis. Hal ini membuat siswa belum terbiasa dengan kegiatan inkuiri, sehingga pada kegiatan tersebut guru membimbing siswa secara penuh.

Pada kegiatan pengamatan guru belum mampu mengkondisikan siswa dengan baik, guru juga belum menerapkan langkah pembelajaran menggunakan model CTL yaitu memberikan penilaian dan merefleksi kegiatan pembelajaran bersama siswa. Pembelajaran ini terjadi karena guru masih pertama dalam melaksanakan pembelajaran dan belum terampil dalam mengajar. Hal ini dikuatkan pendapat Anitah (2009: 7.4) bahwa pembelajaran dapat berhasil apabila guru memiliki keterampilan dalam mengajar meliputi keterampilan menjelaskan, keterampilan mengelola kelas, keterampilan bertanya, keterampilan mengadakan variasi, dan keterampilan membimbing diskusi kelompok kecil. Belum terampilnya guru dalam melaksanakan pembelajaran membuat siswa belum maksimal dalam melakukan kegiatan pengamatan. Karena ketika guru membimbing siswa dalam satu kelompok, maka siswa lain asik bermain dan sikap tanggung jawab siswa untuk bekerjasama dalam kelompok kurang. Siswa belum mandiri dan belum dapat dikondisikan pada kegiatan pembelajaran karena siswa masih adaptasi dengan model pembelajaran yang baru diterapkan guru dalam proses pembelajaran. Sehingga siswa masih memerlukan arahan dan bimbingan dari guru, hal ini sesuai dengan teori Vygotsky (dalam Trianto, 2007: 107) yaitu scaffolding. Scaffolding adalah memberikan bantuan kepada siswa selama tahap awal pembelajaran dan kemudian mengurangi bantuan tersebut sehingga siswa dapat mandiri.

Langkah pembelajaran yang belum dilakukan oleh guru adalah guru belum memberikan penilaian pada naskah akhir puisi dan guru belum merefleksi pembelajaran. Kegiatan penilaian dan merefleksi pembelajaran belum dilakukan guru karena waktu pembelajaran sudah selesai. Hal ini tidak sesuai dengan langkah pembelajaran menulis puisi menggunakan model CTL menurut Trianto dan Haryadi yang terdiri dari 3 kegiatan. Kegiatan awal meliputi (1) menyiapkan fisik dan psikis siswa, (2) melakukan kegiatan apersepsi, dan (3) melakukan kegiatan penyampaian materi pembelajaran. Kegiatan inti meliputi (1) mengembangkan pemikiran siswa akan belajar sendiri, menemukan dan mengkonstruksi pengetahuan dan keterampilan barunya untuk menulis puisi dengan langkah awal yaitu menentukan tema, (2) melaksanakan sejauh mungkin kegiatan inkuiri dalam tahap mengumpulkan bahan, (3) mengembangkan sifat ingin tahu siswa dengan bertanya dalam tahap menyusun bahan, (4) menciptakan masyarakat belajar dalam tahap menulis kerangka, (5) menghadirkan model sebagai contoh pembelajaran untuk mendukung dalam tahap menulis naskah awal, (6) melakukan refleksi dalam tahap revisi, dan (7) memberikan penilaian pada naskah akhir puisi. Kegiatan penutup meliputi (1) merefleksi pembelajaran, (2) menarik kesimpulan dan memberi penguatan materi, dan (3) membimbing siswa dalam kegiatan berdoa dan mengucapkan salam.

Pembelajaran pada siklus II dilaksanakan berdasarkan refleksi dari tindakan siklus I. Pembelajaran yang dilakukan sudah berjalan 
dengan cukup baik karena guru sudah cukup terampil dalam melaksanakan kegiatan pembelajaran sehingga tujuan pembelajaran tercapai. Pada siklus II yang dilakukan oleh guru sudah melibatkan siswa secara aktif melalui kegiatan inkuiri dengan menemukan sendiri bahan yang diperlukan dalam menulis puisi dan mengumpulkan bahan tersebut. Pada kegiatan ini siswa antusias dalam pembelajaran karena siswa sudah terbiasa dengan pembelajaran menulis puisi dan siswa sudah mandiri dalam mengerjakan tugas, sehingga guru hanya mengawasi siswa dalam pembelajaran.

Pembelajaranmenulis puisiyangdilakukan oleh guru berdasar pada kegiatan pengamatan, dalam hal ini guru sudah menggunakan lingkungan nyata sebagai sumber belajar. Pada siklus II siswa sudah dapat menulis puisi berdasar pengamatan yang dilakukan. Hal ini sesuai dengan pendapat Trianto (2007: 103) bahwa model CTL merupakan suatu cara pe-nyajian pembelajaran yang mengaitkan antara materi yang diajarkannya dengan situasi dunia nyata siswa dengan tujuan untuk belajar dengan mengamati atau mengalami secara langsung. Pada kegiatan pengamatan guru sudah mampu mengkondisikan siswa dengan baik, karena sikap tanggung jawab siswa sudah meningkat sehingga siswa aktif bekerja bersama kelompok Guru dan siswa sudah melakukan proses pembelajaran dengan menerapkan model CTL secara keseluruhan, sehingga diperoleh data persentase aktivitas guru dan aktivitas siswa meningkat. Data persentase aktivitas guru dan aktivitas siswa diperoleh dari hasil observasi. Persentase aktivitas guru dalam pembelajaran menulis puisi menggunakan model CTL pada siklus I pertemuan 1 adalah $77 \%$ meningkat pada siklus I pertemuan 2 sebesar $85 \%$, sehingga rata-rata persentase aktivitas guru pada siklus I sebesar $81 \%$. Pada siklus II pertemuan 1, persentase aktivitas guru adalah 92\% meningkat pada siklus II pertemuan 2 sebesar $100 \%$, sehingga rata-rata persentase aktivitas guru pada siklus II sebesar 96\%. Pada siklus I pertemuan 1 persentase aktivitas siswa adalah
$61 \%$ meningkat pada siklus I pertemuan 2 sebesar $77 \%$ sehingga rata-rata persentase aktivitas siswa adalah 69\%. Pada siklus II pertemuan 1 persentase aktivitas siswa adalah $85 \%$ meningkat pada siklus II pertemuan 2 sebesar $100 \%$, sehingga rata-rata persentase aktivitas siswa adalah $92 \%$.

Peningkatan tersebut membuktikan bahwa dengan menerapkan model CTL dapat meningkatkan aktivitas guru dan aktivitas siswa dalam proses pembelajaran bahasa Indonesia materi menulis puisi pada siswa kelas III SDI Darut Taqwa Beji Tulungagung. Peningkatan aktivitas siswa dalam penerapan model CTL sesuai dengan Shoimin (2014: 44) bahwa pembelajaran kontekstual dapat meningkatkan aktivitas berpikir siswa secara penuh, baik fisik maupun mental dan menjadikan siswa belajar bukan dengan menghafal, melainkan proses berpengalaman di dunia nyata.

\section{Peningkatan hasil keterampilan menulis puisi setelah dilakukan penerapan model CTL pada siswa kelas III SDI Darut Taqwa Beji Tulungagung}

Hasil keterampilan siswa dalam pembelajaran menulis puisi pada siklus 1 masih kurang, karena siswa belum mengerti cara menulis puisi. Menulis puisi menurut $\mathrm{Ru}-$ midjan (2013:74) adalah mengekspresikan pemikiran dan perasaan seorang yang diubah dalam wujud dan bahasa yang paling berkesan, serta dapat menggambarkan sebuah makna. Nilai keterampilan yang diberikan adalah sebuah puisi yang tulisannya memuat keindahan dan kaya akan makna. Sebuah puisi dapat dikatakan indah apabila dibuat dengan memperhatikan unsur-unsur yang terdapat didalamnya. Hal ini sesuai dengan pendapat Badriyah (dalam Rosdiana, 2009:7.15) unsur pembangun puisi terdiri dari tema, amanat, diksi, imajinasi dan gaya bahasa.

Berdasarkan pembelajaran menulis puisi melalui model CTL, diketahui hasil keterampilan siswa pada siklus I masih rendah, dikarenakan siswa masih beradaptasi dengan materi pembelajaran menulis puisi yang dia- 
jarkan guru. Berdasarkan persentase KBK diketahui bahwa dari siklus I mengalami peningkatan sebesar $32 \%$ pada siklus II. Peningkatan hasil keterampilan ini terjadi karena siswa sudah terbiasa dengan menulis puisi melalui pengamatan. Hal ini sesuai dengan tahap perkembangan kognitif Piaget yaitu tahap operasional konkrit. Tahap ini merupakan tahap dimana anak sudah mampu berfikir rasional berdasarkan pada benda-benda nyata.

Peningkatan hasil keterampilan ini terjadi karena siswa sudah terbiasa dengan pembelajaran menulis puisi yang diajarkan guru. Siswa terampil dalam menentukan tema puisi, memilih diksi untuk menulis puisi, menerapkan imajinasi, dan menggunakan gaya bahasa. Hal ini sesuai dengan Roestiyah (2004:125) bahwa latihan secara terus menerus dapat menanamkan kebiasaan dan dapat meningkatkan keterampilan siswa dalam menulis puisi. Keterampilan siswa ini meningkatkan nilai keterampilan siswa sehingga memenuhi KKM yang ditentukan.

Hal tersebut berdampak pada hasil keterampilan siswa yang mengalami peningkatan. Pada siklus I pertemuan 1 rata-rata nilai keterampilan adalah 71 dengan persentase KBK sebesar $50 \%$ dan pada pertemuan 2 ratarata nilai adalah 77 dengan persentase KBK sebesar $75 \%$. Hasil rata-rata nilai keterampilan siswa pada siklus 1 adalah 74 dengan persentase KBK sebesar $62 \%$. Pada siklus II pertemuan 1 rata-rata nilai keterampilan siswa adalah 86 dengan persentase KBK sebesar $100 \%$ dan pada pertemuan 2 rata-rata nilai adalah 81 dengan persentase KBK sebesar $87 \%$. Hasil rata-rata nilai keterampilan siswa pada siklus II adalah 84 dengan persentase KBK sebesar 94\%.

Dengan demikian dapat dikatakan bahwa penggunaan model CTL dapat meningkatkan hasil keterampilan menulis puisi pada siswa kelas III SDI Darut Taqwa Beji Tulungagung. Peningkatan hasil keterampilan menulis puisi pada penelitian ini sesuai dengan penelitan terdahulu yang dilakukan oleh Pribadi dalam skripsi berjudul "Penerapan CTL untuk Meningkatkan Keterampilan Menulis Puisi Bagi Siswa Kelas 5 SDN Ketawanggede 1 Kota Malang. Dari jumlah 25 siswa pada siklus 1 tingkat ketuntasan mencapai 71,56\% siswa tuntas, dan siklus II mencapai 77,08\% siswa tuntas".

\section{SIMPULAN DAN SARAN}

Penerapan model CTL dalam meningkatkan keterampilan menulis puisi pada siswa kelas III SDI Darut Taqwa Beji Tulungagung sudah dilakukan dengan baik, berjalan dengan lancar, dan sesuai dengan langkah-langkah di RPP. Siswa dan guru telah melaksanakan pembelajaran dengan memanfaatkan lingkungan nyata sebagai sumber belajar, sehingga proses belajar siswa menjadi lebih bermakna dan menyenangkan. Penerapan model CTL dapat meningkatkan keterampilan siswa dalam menulis puisi. Peningkatan terbukti pada siklus I rata-rata nilai adalah 74 dengan KBK sebesar $62 \%$ dan meningkat pada siklus II menjadi 84 dengan KBK sebesar 94\%.

Diharapkan pembelajaran menulis puisi yang dilakukan guru menggunakan model CTL. Hal ini dikarenakan model CTL merupakan model pembelajaran yang memberikan pengalaman belajar secara langsung melalui pengamatan, sehingga siswa lebih mudah dalam menulis puisi, dan meningkatkan keterampilan siswa dalam menulis puisi. Selain pembelajaran menulis puisi, model CTL juga dapat digunakan pada pembelajaran lain karena sifatnya yang menyenangkan, menarik, dan mengaktifkan siswa dalam kegiatan pembelajaran.

\section{DAFTAR RUJUKAN}

Anitah W, Sri. 2009. Strategi Pembelajaran di $S D$. Jakarta: Universitas Terbuka. Arikunto, S, dkk. 2015. Penelitian Tindakan Kelas. Jakarta: PT. Bumi Aksara.

Haryadi, \& Zamzani. 1996. Peningkatan Keterampilan Berbahasa Indonesia. Jakarta: Depdikbud. 
Pribadi Betty Rosmalina. 2011. Skripsi Peningkatan Keterampilan Menulis Puisi Melalui Model Pembelajaran Contextual Teaching and Learning Pada Siswa Kelas 5 SDN Ketawang Gede. Skripsi tidak diterbitkan. Malang: FIP UM.

Roestiyah. 2004. Strategi Belajar Mengajar. Jakarta: Rineka Cipta

Rosdiana, dkk. 2009. Bahasa dan Sastra Indonesia di SD. Jakarta: Universitas Terbuka.
Rumidjan. 2013. Dasar Keilmuan dan Pembelajaran Sastra Anak SD. Malang: Universitas Negeri Malang.

Shoimin, A. 2014. 68 Model Pembelajaran Inovatif dalam Kurikulum 2013. Yogyakarta: Ar-Ruzz Media.

Trianto. 2007. Model-model Pembelajaran Inovatif Berorientasi Konstruktivistik. Jakarta: Prestasi Pustaka 